\title{
Implementasi Kompetensi Sosial Guru Dalam Meningkatkan Motivasi Ekstrinsik Siswa Pada Mata Pelajaran PAI
}

\author{
Teni Tisnia \\ Universitas Islam Nusantara Bandung, Indonesia \\ *Coresponding Author: tenitisnia@gmail.com
}

Article History:

Received 2021-10-22

Revised 2021-11-10

Accepted 2022-01-22

DOI:

10.31949/educatio.v8i2.1602

\begin{abstract}
The phenomenon in the pandemic era is that the learning process is carried out online. In fact, not all students do not have the media to access online learning. This certainly has an impact on the motivation and learning process of students. To collect data, the writer used interview, observation and documentation methods. After the data has been collected, it is analyzed in a qualitative descriptive analysis. After the author presents and the author of the analysis, it can be concluded that: Implementation of teacher social competence in increasing student extrinsic motivation in learning Islamic Religious Education at SMAN 1 Telukajmbe, Karawang Regency is categorized as "going well". The indicator is the increased enthusiasm of students in participating in Islamic Education learning even though learning is done online. The factors that affect the social competence of Islamic Education teachers in increasing students' extrinsic motivation are: Teacher education level, facilities and infrastructure factors, and the establishment of effective communication.

Keywords : teacher social competence, student extrinsic motivation
\end{abstract}

\begin{abstract}
Abstrak
Fenomena di era pandemic ini proses pemelajaran dilakukan melalui daring. Kenyataannya tidak semua peserta didik tidak memiliki media untuk mengakses pembelajaran secara daring. Hal ini tentu berdampak terhadapa motivasi dan proses pembelajaran peserta didik. Penelitian ini dilakukan untuk menjawab rumusan masalah yaitu bagaimanakah Implementasi kompetensi Sosial guru dalam meningkatkan motivasi ekstrinsik siswa pada pembelajaran Pendidikan Agama Islam di SMAN 1 Telukjambe Kabupaten Karawang. Untuk mengumpulkan data penulis menggunakan metode wawancara, observasi dan dokumentasi. Setelah data terkumpul maka dianalisa dalam analisis deskriptif kualitatif.. Setelah penulis sajikan dan penulis analisa, maka dapat disimpulkan bahwa: Implementasi Kompetensi sosial guru dalam meningkatkan motivasi ekstrinsik siswa pada pembelajaran Pendidikan Agama Islam di SMAN 1 Telukajambe Kabupaten Karawang dikategorikan baik. Indikatornya adalah meningkatnya antusias siswa dalam mengikuti pembelajaran PAI meski pembelajaran di lakukan secara daring. Adapun faktor-faktor yang mempengaruhi kompetensi sosial guru PAI dalam meningkatkan motivasi ekstrinsik siswa ini adalah tingkat pendidikan guru, faktor sarana dan prasarana, dan terjalinnya komunikasi yang efektif.
\end{abstract}

Kata Kunci : kompetensi sosial guru, motivasi ekstrinsik siswa

\section{PENDAHULUAN}

Guru adalah profesi yang unik karena begitu banyaknya kompetensi yang harus mereka miliki dalam melaksanakan tugasnya mempersiapkan generasi yang akan dating (Zuhri \& Mutmainah, 2019). Salah satu kompetensi yang harus dimiliki setiap guru adalah kompetensi sosial, yakni kemampuan mengelola hubungan kemasyarakatan yang membutuhkan berbagai keterampilan, kecakapan dan kapasitas dalam menyelesaikan masalah yang terjadi dalam hubungan antar pribadi (Andriyani et al, 2017). Dalam pendidikan Agam Islam, Kompetensi sosial ini berkaitan dengan kemampuan guru dalam bersikap inklusif, objektif, serta tidak diskriminatif berdasarkan jenis kelamin, agama, ras, kondisi fisik, latar belakang keluarga dan status sosial ekonomi (Sari, 2017). Selain itu, kompetensi sosial ini juga berkaitan dengan sikap adaptif dan komunikatif 
seorang guru terhadap komunitas guru, warga sekolah dan masyarakat yang berada di lingkungan tempat bertugas (Meria, 2017; Nurhayati, 2013). Namun sebenarnya dalam praktiknya kompetensi tersebut tidak dapat berjalan sendiri, harus ada kompetensi lain yang mesti terjalin secara terpadu pada diri guru. Sehingga dalam hal ini penulis tidak hanya melihat kompetensi sosial guru pendidikan agama Islam, tetapi kompetensi yang lain juga berperan penting dalam mengatasi kesulitan belajar peserta didik.

Fenomena di era pandemi ini proses pembelajaran dilakukan melalui daring. Kenyataannya tidak semua peserta didik tidak memiliki media untuk mengakses pembelajaran secara daring. Hal ini tentu berdampak terhadapa motivasi dan proses pembelajaran peserta didik. Banyak dari mereka yang mengeluh dan ingin belajar kembali secara tatap muka. Alasannya adalah belajar tatap muka dapat berkomunikasi langsung antara guru dan peserta didik. Berdasakan observasi awal ke tempat penelitian, pada era pembelajaran di rumah (study from home) terdapat beberapa indikasi yang menunjukan bahwa kompetensi sosial guru di Sekolah Menengah Atas Negeri 1 Telukjambe Timur ini cukup komunikatikatif. Sementara di beberapa tempat masih minim guru yang bersikap kurang peduli terhadap minat belajar siswa pada mata pelajaran PAI, masih ada beberapa guru yang berbicara kasar dengan siswa, diantara sebagian dari guru belum bisa bekerjasama secara efektif dengan Orang tua siswa, ada guru yang belum mengikuti komunitas profesi secara rutin dan ada beberapa guru yang belum pernah mengikuti pelatihan motivasi dalam rangka meningkatkan kompetensi, masih ada guru PAI yang kurang mampu menciptakan persaingan/ kompetisi antar siswa, masih ada guru PAI yang kurang memberi pujian terhadap hasil kerja siswa, masih ada siswa yang bermain-main ketika guru memberikan tugas PAI, masih ada siswa yang lalai dalam menunaikan tugas PAI, masih ada siswa yang kurang respon terhadap apa yang disampaikan oleh guru, masih ada siswa yang tidak mengikuti pembelajaran PAI.

Standar Nasional Pendidikan, pada Pasal 28 ayat (3) butir d, dikemukakan bahwa yang dimaksud dengan kompetensi sosial adalah kemampuan pendidik sebagai bagian dari masyarakat untuk berkomunikasi dan bergaul secara efektif dengan peserta didik, sesama pendidik, tenaga kependidikan, orangtua/wali, peserta didik, dan masyarakat sekitar. Kemampuan memotivasi dari pendidik merupakan motivasi ekternal bagi peserta didik. Kompetensi sosial adalah kemampuan guru dalam berkomunikasi dan berinteraksi secara efektif dengan lingkungan sekolah maupun di luar lingkungan sekolah (Wibowo \& Hamrin, 2012).

Keberhasilan proses pembelajaran tidak hanya berasal dari kompetensi guru saja. Peserta didik juga memiliki peran dalam keberhasilan proses pembelajaran. Adanya kesadaran dan keuntukan untuk belajar dari peserta didik juga sangat membantu tercapainya keberhasilan suatu proses pembelajaran. Kesadaran dan keuntukan ini akan tercipta apabila peserta didik memiliki motivasi belajar yang tinggi. Motivasi yang baik dan memadai dapat mendorong siswa menjadi lebih aktif dalam belajar dan dapat meningkatkan prestasi belajar dikelas (Iskandar, 2012; Sari, 2018).

Motivasi yang timbul dari peserta didik merupakan motivasi intrinsik. Motivasi intrinsik berpengaruh terhadap kelangsungan proses belajar peserta didik. Motivasi intrinsik (internal) adalah motivasi di mana perilaku seseorang untuk melakukan atau mencapai sesuatu demi dirinya sendiri. Motivasi Intrinsik adalah motif-motif yang menjadi aktif atau berfungsinya sehingga tidak perlu rangsangan dari luar, karena dari dalam diri individu sudah ada dorongan untuk melakukan sesuatu (Ena \& Djami, 2021; Fithriani, 2021; Umam. 2019). Selain motivasi belajar intrinsik, motivasi yang tidak kalah penting untuk membangkitkan kemauan belajar siswa adalah motivasi belajar ekstrinsik. Motivasi belajar ektrinsik adalah motivasi belajar yang datangnya karena adanya dorongan dari luar diri siswa (Herawati et al, 2021; Kusnandar, 2019; Mubarok, 2019). Untuk itulah guru memiliki kewajiban untuk memberikan dorongan kepada peserta didik dalam meningkatkan motivasi belajarnya, sehingga dengan bantuan itu anak didik dapat keluar dari kesulitan belajar. Motivasi belajar yang rendah dari peserta didik akan berdampak pada suasana belajar yang tidak menyenangkan bagi peserta didik (Wijanarko, 2017).

Berdasarkan latar belakang di atas maka penelitian ini bertujuan untuk menganalisis lebih dalam mengenai implementasi kompetensi sosial guru dalam meningkatkan motivasi ekstrinsik siswa terhadap mata pelajaran PAI di SMAN 1 Telukjambe Timur Kabupaten Karawang. 


\section{METODE PENELITIAN}

Penelitian ini menggunakan metodologi sesuai dengan apa yang akan dibahas, yaitu meliputi jenis metode penelitian, teknik pengumpulan data, dan juga memiliki batasan masalah yang akan dijelaskan sebagai berikut. Penelitian ini penulis menggunakan studi pustaka.

Dalam teknik pengumpulan data penulis akan mengeksplorasi data sesuai dengan pembahasan mengenai implementasi kompetensi sosial guru dalam meningkatkan motivasi ekstrinsik siswa pada mata pelajaran PAI di SMAN 1 Telukjambe. Dalam hal ini data yang diperoleh dari wawancara, berbagai buku dan literatur, dokumen, jurnal, artikel maupun informasi dari media cetak maupun media elektronik lainnya yang relevan dalam masalah-masalah yang diamati. Setelah data dikumpulkan, diseleksi dan dikelompokkan akan dilakukan pembahasan dan analisa.

\section{HASIL DAN PEMBAHASAN}

\section{Tujuan Implementasi Kompetensi Sosial Guru}

Melihat data di lapangan pada saat melakukan penelitian di SMAN 1 Telukjambe. Selain dari hasil observasi lapangan, saya juga melakukan wawancara kepada beberapa pihak terkait yang dapat memberikan informasi sesuai dengan penelitian saya maka didapatkan beberapa hasil yaitu guru yang akan melakukan proses belajar mengajar terlebih dahulu harus membuat sebuah program yang sesuai dengan standart pemerintah, dalam pencapaian sebuah target pembelajaran guru juga harus menyesuaikan dengan beberapa hal yang termaktub dalam rencana pelaksanaan pembelajaran, sudah jelas tertera setelah identitas sekolah dan sebelum masuk ke inti pembelajaran, guru wajib menyampaikan apa tujuan dari materi yang akan di sampaikan, dan siswa harus terlebih dahulu memahami tujuan tersebut sebelum masuk ke dalam pembelajaran inti. Dari hasil kesesuaian berikut guru dan siswa di harapkan dapat menjalankan proses pembelajaran dengan baik. Di lihat dari situasi yang masih pandemi di SMAN 1 Telukjambe ini siswa menjalankan pembelajaran secara daring. Meskipun pembelajaran di laksanakan secara daring namun tidak menyulutkan semangat dan antusias siswa dalam mengikuti kegiatan-kegiatan yang diadakan sekolah terutamanya dalam mata pelajaran PAI, meski demikian guru di SMAN 1 Telukjambe Timur Kabupaten Karawang tidak henti-hentinya berusaha meningkatkan Motivasi Ekstrinsik Siswa agar tidak mudah down saat mengikuti pembelajaran, hal ini dilakukan oleh guru agar dalam proses belajar mengajar dapat berjalan maksimal. Sehingga siswa di SMAN 1 Telukjambe Timur Kabupaten Karawang ini termotivasi dan merasa nyaman dalam mengikuti pelajaran yang disampaikan oleh guru. Oleh karena itu, tujuan implementasi kompetensi social pada guru di SMAN 1 Telukjambe Timur Kabupaten Karawang perlu ditingkatkan lagi, hal ini bertujuan untuk mencapai keberhasilan proses belajar mengajar secara optimal dalam mewujudkan pembentukan manusia muslim yang mampu mengamalkan ajaran agama Islam dalam kehidupan sehari-hari dan dapat dijadikan sebagai pedoman hidup sesuai dengan visi dan misi dari SMAN 1 Telukjambe Karawang Kabupaten Karawang itu sendiri.

2. Pelaksanaan Implementasi Kompetensi Sosial Guru

Keberhasilan proses pendidikan banyak dipengaruhi oleh interaksi sosial antara guru dan peserta didik, guru dan orang tua peserta didik, guru dan tenaga kependidikan lainnya, dan hubungan guru dengan masyarakat. Sifat interaksi ini banyak bergantung pada tindakan guru yang ditentukan oleh peran nya di sekolah dan dalam lingkungan masyarakat sekitar. Reaksi peserta didik, masyarakat, sesama guru dan orang tua peserta didik dapat diketahui dari ucapan dan pendapat mereka tentang guru tersebut.

Berdasarkan hasil penelitian, dapat disimpulkan bahwa guru Pendidikan Agama Islam di SMAN 1 Telukjambe Kabupaten Karawang bersikap inklusif dan bertindak objektif terhadap peserta didik, teman sejawat dan lingkungan sekitar dalam melaksanakan pembelajaran. Hal tersebut terlihat bahwa semua guru Pendidikan Agama Islam di SMAN 1 Telukjambe Kabupaten Karawang dalam melaksanakan pembelajaran, guru sangat terbuka menerima perbedaan dan bertindak objektif dalam hal memberikan penilaian terhadap peserta didiknya, serta memperlakukan para siswanya, teman guru, dan lingkungan sekitar secara proposional (adil). Guru Pendidikan Agama Islam di SMAN 1 Telukjambe Kabupaten Karawang dalam menjalin hubungan dengan peserta didik dilandasi dengan kasih sayang dan menghindarkan diri dari tindak kekerasan 
fisik. Hal tersebut sependapat dengan dengan Mulyasa yang menyatakan bahwa hubungan yang terjalin antara guru dengan peserta didik dilandasi dengan kasih sayang dan menghindarkan diri dari tindak kekerasan fisik yang diluar batas kaidah pendidikan dan guru memandang semua tindakan peserta didik secara proposional (adil).

3. Hasil (Evaluasi) Implementasi Kompetensi Sosial Guru

Hasil dari proses pelaksanaan kompetensi sosial di SMAN 1 Telukjambe Karawang berjalan dengan baik, hal ini dapat di lihat dari upaya keras guru dalam memberi stimulans sebelum pembelajaran, selain itu meski pembelajaran dilaksanakan secara daring tetapi guru tetap berupaya sebisa mungkin siswa bisa mengikuti pembelajaran dengan baik, apabila siswa tidak bisa mengikuti pembelajaran secara tatap muka online, guru menggantinya dengan penugasan. Penugasan bisa di kumpulkan secara online atau bisa langsung di berikan kepada guru di sekolah.

4. Faktor Pendukung Serta Penghambat Implementasi Kompetensi Sosial Guru

Proses penerapan kompetensi sosial dalam meningkatkan kompetensi sosial peserta didik di SMAN 1 Telukjambe Karawang memiliki faktor pendukung dan penghambat. Adapun faktor pendukungnya (1) guru yang memiliki kualifikasi akademik, dan (2) peranan Humas (Hubungan Masyarakat). Adapun yang menjadi faktor penghambatnya ialah (1) kurangnya Komunikasi dengan Teman Seprofesi; dan (2) kurangnya Komunikasi dengan Orang Tua Peserta Didik dan Masyarakat Sekitar SMAN 1 Telukjambe Karawang

\section{KESIMPULAN}

Implementasi kompetensi sosial guru dalam meningkatkan motivasi ekstrinsik siswa pada mata pelajaran PAI di SMAN 1 Telukjambe Timur Kabupaten Karawang menunjukan kompetensi sosial guru sudah sesuai dengan standar pemerintah dan anak didik termotivasi untuk mengikuti pembelajaran dan melaksanakan tugas-tugas sesuai dengan arahan guru pada era. Pelaksanaan dan evaluasi implementasi kompetensi sosial guru dalam meningkatkan motivasi ekstrinsik siswa pada mata pelajaran PAI di SMAN 1 Telukjambe Timur Kabupaten Karawang cukup baik.

\section{DAFTAR PUSTAKA}

Andriyani, F., Dasar, J. P. G. S., \& Pemerintah, D. P. (2017). Membangun Kompetensi Guru Sebagai Upaya Membentuk Generasi Yang Utuh. Jurnal Pendidikan Guru Sekolah Dasar, 1-11.

Ena, Z., \& Djami, S. H. (2021). Peranan motivasi intrinsik dan motivasi ekstrinsik terhadap minat personel bhabinkamtibmas polres kupang kota. Among Makarti, 13(2).

Fithriani, F. (2021). Peran Orang Tua Memberikan Motivasi Terhadap Prestasi Anak Dalam Keluarga. Intelektualita, 9(02).

Herawati, F., Purwani, R., \& Ratnasari, F. (2021). Hubungan Motivasi Dengan Minat Belajar Bahasa Inggris Pada Siswa-Siswi Di Ma Al-Istiqomah Kabupaten Tangerang Tahun 2020. Nusantara Hasana Journal, 1(2), 46-55.

Iskandar. (2012). Psikologi Pendidikan Sebuah Orientasi Baru. Jakarta:Referensi.

Kusnandar, D. (2019). Pengaruh Model Problem Based Learning Terhadap Hasil Belajar Kognitif dan Motivasi Belajar IPA. Madrascience: Jurnal Pendidikan Islam, Sains, Sosial, dan Budaya, 1(1), 17-30.

Meria, A. (2017). Kompetensi Guru Kelas Madrasah Ibtidaiyah. Tarbiyah al-Awlad, 7(2).

Mubarok, T. A. (2019). Motivasi Belajar Bahasa Inggris pada Siswa Madrasah Aliyah Darul Mutallimin Sugihwaras Patianrowo Nganjuk. Briliant: Jurnal Riset dan Konseptual, 4(1), 118-124.

Nurhayati, S. (2013). Hubungan kinerja supervisor dengan tingkat kompetensi guru sekolah dasar di kota Malang. Jurnal Kebijakan dan Pengembangan Pendidikan, 1(2).

Sari, I. (2018). Motivasi belajar mahasiswa program studi manajemen dalam penguasaan keterampilan berbicara (speaking) bahasa Inggris. Jumant, 9(1), 41-52. 
Sari, N. (2017). Menjadi Guru Profesional di Era Globalisasi. Jurnal Dosen Universitas PGRI Palembang.

Umam, M. K. (2019). Penggunaan metode Jaritmatika dalam meningkatkan motivasi belajar. Awwaliyab: Jumal Pendidikan Guru Madrasah Ibtidaiyah, 2(1), 45-68.

Wibowo, A. \&, Hamrin. (2012). Menjadi Guru Berkarakter: Strategi Membangun Kompetensi \& Karakter Guru . Cet. I; Yogyakarta: Pustaka Pelajar.

Zuhri, S., \& Mutmainah, M. (2019). Pengaruh Kompetensi Sosial Guru Dan Pola Asuh Orang Tua Terhadap Iklim Belajar di Kelas IX SMP Muhammadiyah Serpong, Tangerang Selatan, Banten. el-Moona| Jurnal Ilmu Pendidikan Islam, 1(2), 149-176. 